\title{
Impact of Financial Technology (Fintech) on Financial Inclusion(FI) in Rural India
}

\author{
Shubham Goswami ${ }^{1, *}$, Raj Bahadur Sharma ${ }^{2}$, Vineet Chouhan ${ }^{1}$ \\ ${ }^{1}$ School of Management, Sir Padampat Singhania University, Bhatewar, Udaipur-313601, India \\ ${ }^{2}$ Department of Accounting, College of Business Administration, University of Bahrain, Kingdom of Bahrain
}

Received November 27, 2021; Revised December 26, 2021; Accepted February 8, 2022

\section{Cite This Paper in the following Citation Styles}

(a): [1] Shubham Goswami, Raj Bahadur Sharma, Vineet Chouhan, "Impact of Financial Technology (Fintech) on Financial Inclusion(FI) in Rural India," Universal Journal of Accounting and Finance, Vol. 10, No. 2, pp. 483 - 497, 2022. DOI: 10.13189/ujaf.2022.100213.

(b): Shubham Goswami, Raj Bahadur Sharma, Vineet Chouhan (2022). Impact of Financial Technology (Fintech) on Financial Inclusion(FI) in Rural India. Universal Journal of Accounting and Finance, 10(2), 483 - 497. DOI: 10.13189/ujaf.2022.100213.

Copyright $@ 2022$ by authors, all rights reserved. Authors agree that this article remains permanently open access under the terms of the Creative Commons Attribution License 4.0 International License

\begin{abstract}
Transformation towards Financial technology makes possibilities throughout all areas of the economy for growth. Emerging developing economies have seen a fast expansion of financial technology and mobile money services. FinTech projects, which are regarded as some of the most significant advances in the financial sector, have also obviously been driven by the growth of digital transformation, as FinTech Mobile money and digital wallets address the economic infrastructure vacuum with an innovative technology solution and enable customers to conduct financial transactions affordably and dependably by eliminating spatial barriers, and can be used to bridge the gap of banked

perceived ease of use towards using the financial technology are positively related to the system's usability. Present work provides emerging good practices for policy-makers, regulators, and investors in changing financial environment. It presents empirical findings to identify the critical success factor and another growth driver for FinTech services. The results would help mobile service industry to discover an economy of scope in providing services at low cost and with maximum social benefits. Study will also provide insights to financial institutions for offering banking services via mobile to handle cross-border transactions to low-income customers of remote areas.
\end{abstract} and unbanked. This paper investigates the critical success factors influencing the adoption of disruptive financial technology for financial inclusion in rural India. Present research empirically measures the impact of technology in promoting entrepreneurship in under-developed regions for future adoption of financial technology in rural areas. The quantitative approach uses inferential statistics for hypothesis testing. Exploratory Factor Analysis is being applied for critical factor identification and Structural Equation modeling for measuring the impact of FinTech in financial inclusion in Rural India. The result indicates that factors constructing the social influence also positively impact behavioural intention to use manager technology in the rural sector in India. An end-user habit of using financial technology systems and services has a positive relationship with behavioural intention. Factors affecting
Keywords Financial Technology (FinTech), Financial Inclusion, Developing Economies

\section{Introduction}

India is one of the most extensive countries with rich in minerals, marble, and tourism. However, a prominent tribal and rural area suffers from slow economic growth, poverty, and exclusion from formal financial services [1,2]. With an irregular and unreliable income, managing one's finances is more important for the impoverished than anybody else $[2,3,4,5,6,7]$. They need a wide variety of economic and suitable financial services to meet a wide range of financial 
requirements, such as easy access to savings [8, 9], micro-credits [10, 11], insurance [9, 12], payment and transfer services[13]. But due to the limited access to formal financial services, they use informal channels which are less reliable, insecure, and more expensive than standard services [14, 15].

Financial technology companies (FinTechs) emerged during the global financial crisis of 2007-2008 and have since revolutionised the financial industry by bringing new technologies to bear on the market $[16,17]$. The twin foundations of contemporary banking development are information technology and electronic money transfer systems in technology-based banking [18]. The rapid expansion of mobile networks into previously un-served regions and communities in India during the past decade also served as a growth driver for the cause [19, 20]. Payments banks have provided another alternate route to online and mobile banking, assisting in improving efficiency and lowering costs associated with serving clients in rural and semi-urban regions [11, 21, 22]. Traditional banking service entry barriers have been lowered due to new specialised entrants and innovative business models that have blurred the boundaries between business and technology [23, 24].

Inclusive financial sector development offers two complementary contributions [17, 25]. First, financial inclusion connects excluded individuals to economic development, and second, economic growth draws additional people to the economy and financial system [11, 26]. Inclusive financial developments reduce poverty by financing growth factors like mobilising savings and providing entrepreneurship opportunities to poor people, reducing vulnerability and improving welfare [27, 28, 29]. The Financial Inclusion goal has resulted in various banking formats, including tiny banks, mobile money services, and payment banks for the unbanked people. Financial inclusion has also progressed to include new non-bank Fintech companies competing for a more significant part of the Banking value chain [30,31]. This paper explores the critical success factors (CSF) of the adoption of financial technology and its role in supporting entrepreneurship and employment creation in the rural regions of India.

\section{Reviews of Literature}

The primary objective of initiating the idea of microfinance in developing nations was to promote much needed financial sector for development [32, 33, 34, 35]. FI has been linked to economic growth and development [36]. According to Jack and Suri [37], financial technology innovation may offer cheaper and more efficient options by reducing transaction costs. This also boosts the sales of micro and small businesses by lowering the expenses associated with alternative payment options [38]. Most of these studies emphasise the role of digital money transfers (i.e., remittances) as the channel to risk-sharing and improvements in households' financial welfare [39, 40]. Aron [41] conducts an empirical assessment of mobile money and finds support for its function in enhancing risk-sharing. In addition to the findings from Jack and Suri [37], other noteworthy research like Mbiti and Weil [42] and Wieser and others [43] show that more significant usage of FinTech reduces the use of informal savings methods and boosts remittance transactions. Other related research has examined the impacts of digitalisation on social assistance for the poor $[44,45]$.

Identify the potential opportunities and challenges for various stakeholders [27]. Indian M.F.I.s are on the brink of getting started with rapid change and inclusion of mobile money, as new players explore alternatives and collaborations, and most are keeping a close eye on the area and trying to learn from others' experiences [46] Access to financial services is severely restricted in underdeveloped areas of India due to various institutional flaws and other factors that hinder individuals from realising their particular economic potential and possibilities, resulting in limited economic development [47]. As a result, microfinance programmes have been established in developed countries such as India to assist individuals living in underdeveloped regions such as inner cities [48]. According to estimates, micro finance's global potential and possibilities, i.e., financial services, ranging from 500 to 700 million individuals, with M.F.I.s covering less than one-ninth of the market [34] Since then, the poor's need for financial services has mainly gone unsatisfied [48] which provides a boom in the financial inclusion process in the under-developed area of India[48].The following table presents the significant constructs items and factors used to study the important drivers of financial inclusion. 
Table 1. Research Constructs

\begin{tabular}{|c|c|c|c|}
\hline Construct & Code & Variable & Major Source \\
\hline \multirow{4}{*}{$\begin{array}{l}\text { Behavioural } \\
\text { Intention (BI) }\end{array}$} & BI1 & I plan to be part of financial inclusion with the use of FinTech services & \multirow{4}{*}{$\begin{array}{l}\text { Chouhan, V., Vasita, M. } \\
\text { L., \& Goswami, S. [5]; } \\
\text { Senyo, Ellis \& } \\
\text { Osabutey[49]; Venkatesh } \\
\text { et al.[50] }\end{array}$} \\
\hline & BI2 & $\begin{array}{c}\text { For my transactions, I will always attempt to utilise FinTech-based mobile } \\
\text { services. }\end{array}$ & \\
\hline & ВI3 & I plan to continue to use FinTech for Financial Inclusion & \\
\hline & $\mathrm{BI} 4$ & I plan to be part of Financial Inclusion using FinTech. & \\
\hline \multirow{4}{*}{$\begin{array}{l}\text { Effort-Expectancy } \\
\text { (E.E.) }\end{array}$} & EE1 & FinTech based services are found easy to use & \multirow{4}{*}{$\begin{array}{l}\text { Senyo, Ellis \& Osabutey } \\
\text { [49]; Venkatesh et al.[50] }\end{array}$} \\
\hline & EE2 & $\begin{array}{l}\text { I believe FinTech based financial inclusion Techniques will be simple for } \\
\text { me to grasp and apply }\end{array}$ & \\
\hline & EE3 & $\begin{array}{l}\text { My interaction with FinTech based financial inclusion services will be } \\
\text { clear and understandable }\end{array}$ & \\
\hline & EE4 & $\begin{array}{l}\begin{array}{l}\text { Learning to utilise FinTech based financial inclusion services are easy for } \\
\text { me }\end{array} \\
\end{array}$ & \\
\hline \multirow{3}{*}{$\begin{array}{c}\text { Performance } \\
\text { Expectancy (PE) }\end{array}$} & PE1 & $\begin{array}{l}\text { I find mobile FinTech based financial inclusion services useful for my } \\
\text { daily life }\end{array}$ & \multirow{3}{*}{$\begin{array}{l}\text { Senyo, Ellis \& Osabutey } \\
\text { [49]; Venkatesh et al.[50] }\end{array}$} \\
\hline & PE2 & $\begin{array}{l}\text { Using FinTech based financial inclusion services assists me in completing } \\
\text { financial transactions more swiftly }\end{array}$ & \\
\hline & PE3 & $\begin{array}{l}\text { My financial resources are more productive when I use financial inclusion } \\
\text { services. }\end{array}$ & \\
\hline \multirow{3}{*}{$\begin{array}{l}\text { Social Influence } \\
\text { (S.I.) }\end{array}$} & SI1 & $\begin{array}{l}\text { People expected that I should use FinTech based financial inclusion } \\
\text { services }\end{array}$ & \multirow{3}{*}{$\begin{array}{c}\text { Senyo, Ellis \& } \\
\text { Osabutey[49]; Venkatesh } \\
\text { et al.[50] }\end{array}$} \\
\hline & SI2 & $\begin{array}{c}\text { My friends who influence my behaviour suggested me to use FinTech } \\
\text { based financial inclusion services }\end{array}$ & \\
\hline & SI3 & $\begin{array}{c}\text { People whose views I respect are more likely think that I use FinTech } \\
\text { based financial inclusion services }\end{array}$ & \\
\hline \multirow{3}{*}{$\begin{array}{c}\text { Facilitating } \\
\text { Conditions (FC) }\end{array}$} & FC1 & $\begin{array}{l}\text { I have the device that enables me to use FinTech based financial inclusion } \\
\text { services }\end{array}$ & \multirow{3}{*}{$\begin{array}{l}\text { Senyo, Ellis \& Osabutey } \\
\text { [49]; Venkatesh et al.[50] }\end{array}$} \\
\hline & FC2 & $\begin{array}{l}\text { I am knowledgeable enough to utilise FinTech-based financial inclusion } \\
\text { services. }\end{array}$ & \\
\hline & FC3 & $\begin{array}{c}\text { Financial inclusion via FinTech services are compatible with each other } \\
\text { (like payment from Phone pay to Paytm) }\end{array}$ & \\
\hline \multirow{3}{*}{ Motivation (Mot) } & HM1 & Using FinTech based financial inclusion services is fun. & \multirow{3}{*}{$\begin{array}{l}\text { Senyo, Ellis \& Osabutey } \\
\text { [49]; Venkatesh et al.[50] }\end{array}$} \\
\hline & HM2 & Using FinTech based financial inclusion services is enjoyable. & \\
\hline & HM3 & Using FinTech based financial inclusion services is very entertaining. & \\
\hline \multirow{3}{*}{ Habit (H.A.B.) } & HAB1 & I am addicted to using FinTech based financial inclusion services & \multirow{3}{*}{$\begin{array}{l}\text { Senyo, Ellis \& Osabutey } \\
\text { [49]; Venkatesh et al.[50] }\end{array}$} \\
\hline & HAB2 & I must use FinTech based financial inclusion services & \\
\hline & HAB3 & $\begin{array}{l}\begin{array}{l}\text { The use of FinTech based financial inclusion services has become a habit } \\
\text { for me }\end{array} \\
\end{array}$ & \\
\hline \multirow{5}{*}{$\begin{array}{l}\text { Perceived Risk } \\
\quad \text { (P.R.) }\end{array}$} & PR1 & $\begin{array}{l}\text { I believe that utilising FinTech-based financial inclusion services } \\
\text { jeopardises my privacy. }\end{array}$ & \multirow{5}{*}{$\begin{array}{l}\text { Senyo, Ellis \& Osabutey } \\
\text { [49]; Venkatesh et al.[50] }\end{array}$} \\
\hline & PR2 & $\begin{array}{l}\text { The use of FinTech-based financial inclusion services entails greater } \\
\text { financial risk. }\end{array}$ & \\
\hline & PR3 & $\begin{array}{l}\text { There are too many things not known related with FinTech-based } \\
\text { financial inclusion offerings. }\end{array}$ & \\
\hline & PR4 & $\begin{array}{c}\text { Transactions based on FinTech for financial inclusion are not sufficiently } \\
\text { protected by legislation. }\end{array}$ & \\
\hline & PR5 & The use of FinTech based financial inclusion services has potential risk & \\
\hline \multirow{3}{*}{$\begin{array}{l}\text { Service Charges } \\
\text { (S.C.) }\end{array}$} & SC1 & Service charges under FinTech based financial inclusion are reasonable & \multirow{3}{*}{$\begin{array}{c}\text { Senyo, Ellis \& Osabutey } \\
\text { [49]; Venkatesh et al. } \\
\text { [50] }\end{array}$} \\
\hline & SC2 & Service charges of FinTech based financial inclusion are value for money & \\
\hline & SC3 & $\begin{array}{l}\text { The transaction fee for FinTech based financial inclusion services is } \\
\text { expensive }\end{array}$ & \\
\hline \multirow{3}{*}{ Agent Trust (AT) } & AT1 & $\begin{array}{l}\text { I have faith in the agents who provide FinTech-based financial inclusion } \\
\text { services. }\end{array}$ & \multirow{3}{*}{$\begin{array}{l}\text { Senyo, Ellis } \\
\text { \&Osabutey[49]; } \\
\text { Venkatesh et al.[50]; } \\
\text { Gefen et.al.,[51]; } \\
\text { Pavlou, [52] }\end{array}$} \\
\hline & AT2 & $\begin{array}{l}\text { The FinTech-based financial inclusion service agent stands to lose more if } \\
\text { my transactions are not processed. }\end{array}$ & \\
\hline & AT3 & $\begin{array}{l}\text { I believe it is essential to exercise caution when it comes to FinTech-based } \\
\text { financial inclusion offerings. }\end{array}$ & \\
\hline
\end{tabular}


Table 1 Continued

\begin{tabular}{|c|c|c|c|}
\hline \multirow{3}{*}{$\begin{array}{l}\text { Service Trust } \\
\text { (S.T.) }\end{array}$} & ST1 & FinTech based financial inclusion services is found to be trustworthy & \multirow{3}{*}{$\begin{array}{c}\text { Senyo, Ellis \& Osabutey } \\
\text { [49] ; Gefen et.al.,[51]; } \\
\text { Pavlou, [52] }\end{array}$} \\
\hline & ST2 & $\begin{array}{l}\text { It is essential to take proper care with FinTech based financial inclusion } \\
\text { services }\end{array}$ & \\
\hline & ST3 & I trust FinTech based financial inclusion services as past experience & \\
\hline \multirow{3}{*}{ Usability (U.B.) } & UB1 & I am likely to use FinTech based financial inclusion services & \multirow{3}{*}{$\begin{array}{l}\text { Senyo, Ellis \& Osabutey } \\
\text { [49]; Venkatesh et al. [50] }\end{array}$} \\
\hline & UB2 & I use FinTech based financial inclusion services frequently & \\
\hline & UB3 & I use FinTech based services a lot. & \\
\hline \multirow{3}{*}{$\begin{array}{l}\text { Perceived } \\
\text { ease-of-use } \\
\text { (PEOU) }\end{array}$} & PEOU1 & $\begin{array}{l}\text { I think that it is easy to make FinTech based financial inclusion service } \\
\text { transactions }\end{array}$ & \multirow{3}{*}{$\begin{array}{l}\text { Meyliana, M., \& Fernando, } \\
\text { E. [53]; Rose, J., \& } \\
\text { Fogarty, G. J. [54]; Davis, } \\
\text { F. D. [55] }\end{array}$} \\
\hline & PEOU2 & $\begin{array}{l}\text { I think that interaction with FinTech based F.I. services does not } \\
\text { require a lot of mental effort. }\end{array}$ & \\
\hline & PEOU3 & $\begin{array}{l}\text { Learning to use FinTech based financial inclusion service would be } \\
\text { easy }\end{array}$ & \\
\hline \multirow{4}{*}{$\begin{array}{c}\text { Perceived } \\
\text { Usefulness (P.U.) }\end{array}$} & PU1 & $\begin{array}{c}\text { Using FinTech based financial inclusion services will improve the } \\
\text { profitability of my savings }\end{array}$ & \multirow{4}{*}{$\begin{array}{l}\text { Subramanian, G. H. [56] ; } \\
\text { Davis, F. D.[55]. }\end{array}$} \\
\hline & PU2 & $\begin{array}{l}\text { Using FinTech based financial inclusion services will allow me to send } \\
\text { money inexpensively to anyone in the world }\end{array}$ & \\
\hline & PU3 & $\begin{array}{l}\text { Using FinTech based financial inclusion services will improve my } \\
\text { financial performance }\end{array}$ & \\
\hline & PU4 & $\begin{array}{l}\text { Using FinTech based financial inclusion services will allow me to } \\
\text { increase my productivity }\end{array}$ & \\
\hline \multirow{3}{*}{$\begin{array}{l}\text { Fintech Use for } \\
\text { Financial } \\
\text { Inclusion }\end{array}$} & FTFI1 & Fintech can be used for Financial Inclusion in rural India & \multirow{3}{*}{$\begin{array}{c}\text { Demir, A., Pesqué-Cela, } \\
\text { V., Altunbas, Y., \& } \\
\text { Murinde, V. [57]; Thomas, } \\
\text { H., \& Hedrick-Wong, Y. } \\
\text { [58]. }\end{array}$} \\
\hline & FTFI2 & $\begin{array}{l}\text { Fintech can be used for Financial Inclusion with income improvement } \\
\text { in rural India }\end{array}$ & \\
\hline & FTFI3 & $\begin{array}{l}\text { Fintech can be used for Financial Inclusion with saving improvement in } \\
\text { rural India }\end{array}$ & \\
\hline
\end{tabular}

\section{Research Gap\& Objectives}

Exclusion from the official financial system is rapidly being highlighted as an obstacle to a future free of poverty. Stakeholders of the FinTech ecosystem suffer from procedural and cultural constraints. Researchers are also split on whether mobile money systems realise their full development potential in the rural sector [1, 9]. A study on financial inclusion for Bottom of the Pyramid (B.O.P.) in Indian society also requires a shift and emphasis to design technology solutions for the unreached population $[8,11]$. Hence, to find new methods of financial services to the underprivileged has now become a pressing issue.

Past reviews on the adoption and socio-economic impacts of financial technology in inclusion are rare in the underdeveloped world [10]. Very small consideration has been given to the social, economic, and cultural contexts in which these systems are utilised. Moreover, lack of empirical studies in the context of India exists that identify the critical success factor for the use of technology in expanding financial services $[12,13]$. One of the paper's goals includes calling attention to this gap in the research literature and emphasising the need for research focusing on inclusion and empowerment of the poor. Moreover, using an empirical investigation of entrepreneurial endeavours from disadvantaged communities, the present study will attempt to uncover constraints facing a developing economy and analyse the role of digital technologies in employment generation and poverty reduction [22, 24].

Few empirical studies related to developing economies to identify the critical success factor for financial inclusion using mobile technology [23, 25, 26, 27]. The proposed study appears more contextual for poverty reduction in under-developed regions and provides emerging good practices for policy-makers, regulators, and investors in this complex and ever-changing industry [11, 31]. The proposed paper aims to fill the literature gap in studies on financial inclusion and financial technology in providing financial services. Present research empirically measures the impact of technology in promoting entrepreneurship in under-developed regions and identifies the critical success factors for future adoption of financial technology in rural areas $[17,18]$. Our research work uses both qualitative and quantitative approaches. The qualitative approach is used to understand various adoption theories and psychological factors related to technology adoption [20, 59].The quantitative approach uses inferential statistics for hypothesis testing. Exploratory Factor Analysis (E.F.A.) is being applied for critical factor identification and Structural Equation modelling (S.E.M.) for measuring the impact of FinTech in financial inclusion in Rural India.

\section{Research Objectives}

- To identify the variables that significantly influence adopting financial technologies in rural India. 
- To study the impact of financial technologies (FinTech) on influencing the development goals of financial inclusion development in Rural India.

\section{Research Methodology}

\section{Conceptual Framework}

In an endeavour to investigate the motivational influences for the adoption of technology-based financial services, the present study draws the theoretical framework based on the structure of Theory of Reasoned Action
(T.R.A.) [60], Theory of Planned Behavior (TPB) [61], Technology Acceptance Model (T.A.M.) [62] and Unified Theory of Acceptance and Use of Technology UTAUT [63]. T.A.M. and UTAUT are the most suitable instruments for evaluating technology-based adoption since they have been utilised in numerous researches to predict and understand user perceptions of system usage. Considerable study has been conducted to investigate the effect of risk on conventional consumer decision making [64]. Therefore, the present research model will also consider perceived risk as influencing factors in accepting fintech services.

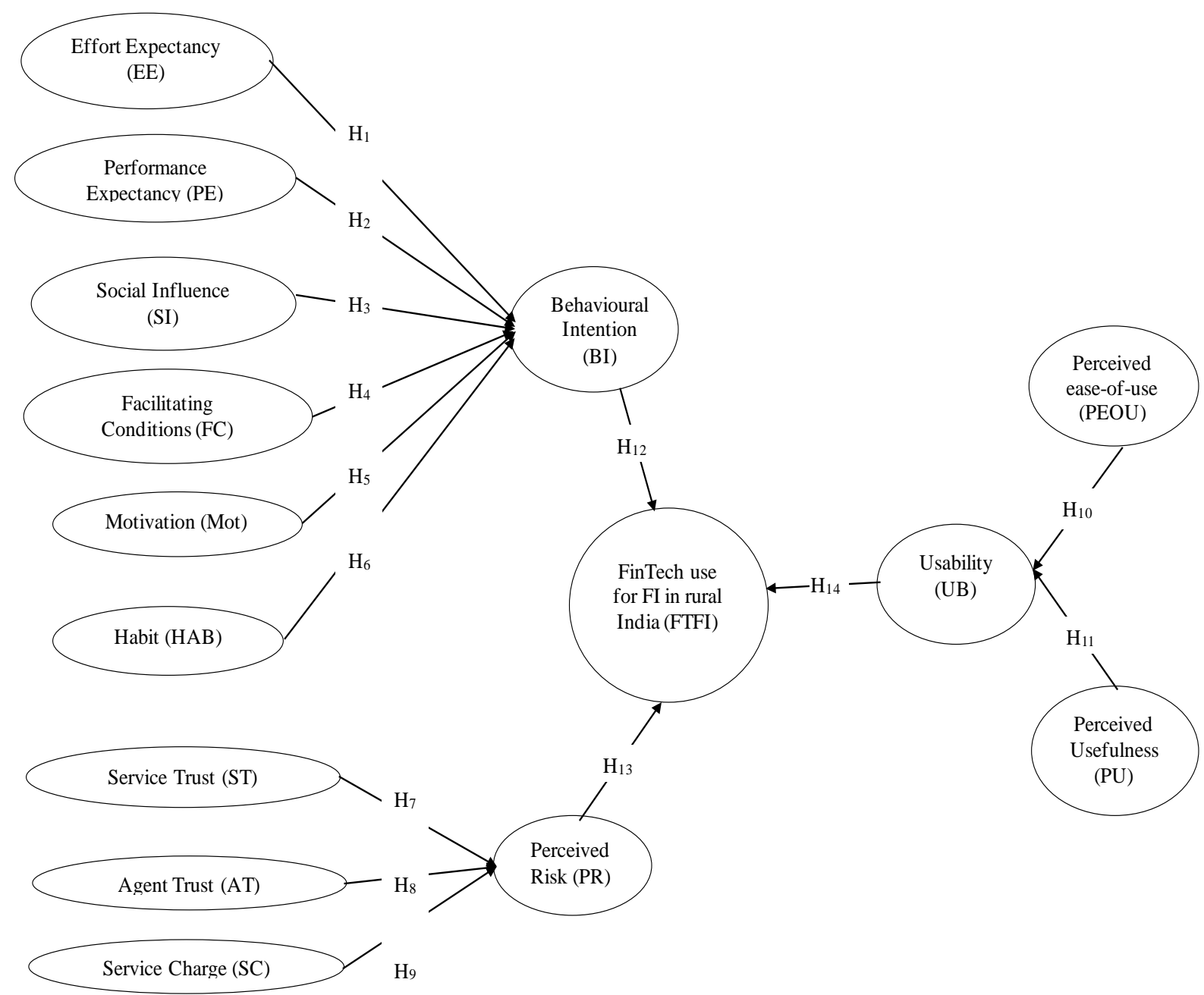

Figure 1. Research Model 


\section{Sample Design}

The Universe of the study as the targeted population for the survey includes users of financial technology and rural entrepreneurs using mobile money and financial technology services. As per the population of 130 Crores, it is not possible to take the views of population and thus the sampling method is institutionalised. The Sampling frame includes respondents assorted based on demographic profile with Stratified Judgmental Sampling. The Sample size for the study was 6050 respondents. Proper care is taken while selecting the respondnets, as only those were included in the study having the experience of using the mobile money services at least from last 6 months. The data for the survey is gathered as per the country's geographical regions by selecting 600 rural districts. The sample is gathered from the central states in India based upon the rural population including the state of Rajasthan, Madhyapradesh, Maharastra, Uttar Pradesh, Punjab and Hariyana. For each of 6 states, the rural population data are collected as per the population survey of India-2011. From each state the sample of 1000 rural respondents is taken.

\section{Data Collection Method}

The data collection technique includes primary and secondary data sources-a survey method used for primary data collection. Primary data was collected from major rural regions in India using stratified sampling techniques. A structured Questionnaire was tested using a pilot survey from consumers of mobile money and other financial technologies. The questionnaire was prepared using a Likert-Rating scale along with a nominal and rank-order scale for data scaling. The questionnaire was pretested for reliability Cronbach alpha and validity using a pilot survey.

\section{Data Analysis Technique}

\section{1) Stage I - Exploratory Research}

In the preliminary stage of the study, an Exploratory Factor Analysis (E.F.A.) was an essential tool for identifying factors of adoption of financial technologies.

\section{2) Stage II - Conclusive Research}

At the conclusive research stage, the existence and strength of the relationship are tested using statistical tests. The primary statistical tool used to test the hypotheses is the Structure Equation Model (S.E.M.) to analyse the impact of FinTech for financial inclusion using mobile money services.

\section{Results}

Each FinTech-related question was asked in the assessment to explain the respondents' responses, and the mean and standard deviation for both measures were calculated appropriately. Tables 2 and 3 include descriptive figures. The values reflect a favourable perspective on the statement regarding Effort Expectancy, Performance Expectancy, Social Influence, Facilitating Conditions, Habit, and Perceived Risk. The results of the measures are shown in Tables 3 and 4.

Table 2. Descriptive Statistics

\begin{tabular}{|c|c|c|c|}
\hline & & & $\mathrm{N}=\mathbf{6 0 5 0}$ \\
\hline Particular & SPSS Code & Mean & Std. Deviation \\
\hline \multicolumn{2}{|l|}{ Behavioural Intention (BI) } & 5.1572 & 1.03120 \\
\hline I plan to be part of financial inclusion with the use of FinTech services & BI1 & 5.4059 & 1.22112 \\
\hline For my transactions, I will always attempt to utilise FinTech-based mobile services. & BI2 & 4.7723 & 1.46619 \\
\hline I plan to continue to use FinTech for Financial Inclusion & BI3 & 5.0842 & 1.49970 \\
\hline I plan to be part of Financial Inclusion using FinTech. & BI4 & 5.3663 & 1.24958 \\
\hline \multicolumn{2}{|l|}{ Effort Expectancy (EE) } & 5.3614 & .98142 \\
\hline FinTech based services are found easy to use & EE1 & 5.5495 & 1.19918 \\
\hline $\begin{array}{l}\text { I believe FinTech based financial inclusion Techniques will be simple for me to grasp and } \\
\text { apply }\end{array}$ & EE2 & 5.3812 & 1.17758 \\
\hline $\begin{array}{l}\text { My interaction with FinTech based financial inclusion services will be clear and } \\
\text { understandable }\end{array}$ & EE3 & 5.5644 & 1.21083 \\
\hline Learning to utilise FinTech based financial inclusion services are easy for me & EE4 & 4.9505 & 1.26655 \\
\hline \multicolumn{2}{|l|}{ Performance Expectancy (PE) } & 4.2706 & 1.29054 \\
\hline I find mobile FinTech based financial inclusion services useful for my daily life & PE1 & 4.4703 & 1.59388 \\
\hline $\begin{array}{l}\text { Using FinTech based financial inclusion services assists me in completing financial } \\
\text { transactions more swiftly }\end{array}$ & PE2 & 3.8812 & 1.60137 \\
\hline My financial resources are more productive when I use financial inclusion services. & PE3 & 4.4604 & 1.59677 \\
\hline
\end{tabular}


Table 2 Continued

\begin{tabular}{|c|c|c|c|}
\hline \multicolumn{2}{|l|}{ Social Influence (SI) } & \multirow{2}{*}{$\begin{array}{l}4.7904 \\
4.7327\end{array}$} & \multirow{2}{*}{$\frac{1.45021}{1.52592}$} \\
\hline People expected that I should use FinTech based financial inclusion services & SI1 & & \\
\hline $\begin{array}{l}\text { My friends who influence my behaviour suggested me to use FinTech based financial } \\
\text { inclusion services }\end{array}$ & SI2 & 4.7376 & 1.57316 \\
\hline $\begin{array}{l}\text { People whose views I respect are more likely think that I use FinTech based financial } \\
\text { inclusion services }\end{array}$ & SI3 & 4.9010 & 1.55561 \\
\hline \multicolumn{2}{|l|}{ Facilitating Conditions (FC) } & 3.5215 & 1.40712 \\
\hline I have the device that enables me to use FinTech based financial inclusion services & FC1 & 4.2030 & 1.75435 \\
\hline I am knowledgeable enough to utilise FinTech-based financial inclusion services. & FC2 & 3.1931 & 1.53548 \\
\hline $\begin{array}{l}\text { Financial inclusion via FinTech services are compatible with each other (like payment from } \\
\text { Phone pay to Paytm) }\end{array}$ & FC3 & 3.1683 & 1.78183 \\
\hline \multicolumn{2}{|l|}{ Motivation (Mot) } & 4.9109 & 1.34504 \\
\hline Using FinTech based financial inclusion services is fun. & HM1 & 4.7277 & 1.69884 \\
\hline Using FinTech based financial inclusion services is enjoyable. & HM2 & 5.2970 & 1.54948 \\
\hline Using FinTech based financial inclusion services is very entertaining. & HM3 & 4.7079 & 1.64508 \\
\hline \multicolumn{2}{|l|}{ Habit (H.A.B.) } & 5.0198 & 1.21635 \\
\hline I am addicted to using FinTech based financial inclusion services & HAB1 & 5.1139 & 1.36977 \\
\hline I must use FinTech based financial inclusion services & HAB2 & 4.9208 & 1.31501 \\
\hline The use of FinTech based financial inclusion services has become a habit for me & НАВ3 & 5.0248 & 1.44121 \\
\hline \multicolumn{2}{|l|}{ Perceived Risk (PR) } & 4.2240 & 1.36532 \\
\hline I believe that utilising FinTech-based financial inclusion services jeopardises my privacy. & PR1 & 5.0693 & 1.51853 \\
\hline The use of FinTech-based financial inclusion services entails greater financial risk. & PR2 & 4.1535 & 1.76781 \\
\hline $\begin{array}{l}\text { There are too many things not known related with FinTech-based financial inclusion } \\
\text { offerings. }\end{array}$ & PR3 & 3.9158 & 1.85183 \\
\hline $\begin{array}{l}\text { Transactions based on FinTech for financial inclusion are not sufficiently protected by } \\
\text { legislation. }\end{array}$ & PR4 & 3.7574 & 1.77743 \\
\hline The use of FinTech based financial inclusion services has potential risk & PR5 & 4.3416 & 1.41789 \\
\hline \multicolumn{2}{|l|}{ Service Charges (SC) } & 4.0446 & 1.87037 \\
\hline Service charges under FinTech based financial inclusion are reasonable & SC1 & 4.5446 & 1.97434 \\
\hline Service charges of FinTech based financial inclusion are value for money & SC2 & 3.7079 & 1.99143 \\
\hline The transaction fee for FinTech based financial inclusion services is expensive & SC3 & 3.8812 & 2.05199 \\
\hline \multicolumn{2}{|l|}{ Agent Trust (AT) } & 4.1601 & 1.69042 \\
\hline I have faith in the agents who provide FinTech-based financial inclusion services. & AT1 & 4.4208 & 1.77759 \\
\hline $\begin{array}{l}\text { The FinTech-based financial inclusion service agent stands to lose more if my transactions } \\
\text { are not processed. }\end{array}$ & AT2 & 4.0891 & 1.80961 \\
\hline $\begin{array}{l}\text { I believe it is essential to exercise caution when it comes to FinTech-based financial } \\
\text { inclusion offerings. }\end{array}$ & AT3 & 3.9703 & 1.86018 \\
\hline \multicolumn{2}{|l|}{ Service Trust (S.T.) } & 3.8449 & 1.63742 \\
\hline FinTech based financial inclusion services is found to be trustworthy & ST1 & 3.8168 & 1.76217 \\
\hline It is essential to take proper care with FinTech based financial inclusion services & ST2 & 3.8812 & 1.71211 \\
\hline I trust FinTech based financial inclusion services as past experience & ST3 & 3.8366 & 1.78924 \\
\hline \multicolumn{2}{|l|}{ Useability (UB) } & 4.2096 & 1.03948 \\
\hline I am likely to use FinTech based financial inclusion services & UB1 & 4.5792 & 1.62303 \\
\hline I use FinTech based financial inclusion services frequently & UB2 & 4.2574 & 1.60054 \\
\hline I use FinTech based services a lot. & UB3 & 3.7921 & 1.51565 \\
\hline \multicolumn{2}{|l|}{ Perceived ease-of-use (PEOU) } & 5.0792 & 1.37482 \\
\hline I think that it is easy to make FinTech based financial inclusion service transactions & PEOU1 & 5.1139 & 1.44722 \\
\hline $\begin{array}{l}\text { I think that interaction with FinTech based F.I. services does not require a lot of mental } \\
\text { effort. }\end{array}$ & PEOU2 & 5.0149 & 1.40652 \\
\hline Learning to use FinTech based financial inclusion service would be easy & PEOU3 & 5.1089 & 1.47979 \\
\hline
\end{tabular}


Table 2 Continued

\begin{tabular}{|c|c|c|c|}
\hline \multicolumn{2}{|l|}{ Perceived Usefulness (PU) } & 4.6089 & 1.36949 \\
\hline $\begin{array}{l}\text { Using FinTech based financial inclusion services will improve the profitability of my } \\
\text { savings }\end{array}$ & PU1 & 4.4505 & 1.62420 \\
\hline $\begin{array}{l}\text { Using FinTech based financial inclusion services will allow me to send money } \\
\text { inexpensively to anyone in the world }\end{array}$ & PU2 & 5.1337 & 1.65353 \\
\hline Using FinTech based financial inclusion services will improve my financial performance & PU3 & 4.6832 & 1.55195 \\
\hline Using FinTech based financial inclusion services will allow me to increase my productivity & PU4 & 4.1683 & 1.62157 \\
\hline \multicolumn{2}{|l|}{ Fintech Use for Financial Inclusion (FTFI) } & 5.0462 & 1.60133 \\
\hline Fintech can be used for Financial Inclusion in rural India & FTFI1 & 4.9851 & 1.66781 \\
\hline Fintech can be used for Financial Inclusion with income improvement in rural India & FTFI2 & 5.0644 & 1.67849 \\
\hline Fintech can be used for Financial Inclusion with saving improvement in rural India & FTFI3 & 5.0891 & 1.69061 \\
\hline
\end{tabular}

Table 3. Model statistics

\begin{tabular}{|c|c|c|c|c|c|c|c|}
\hline \multirow{2}{*}{ Variables } & \multicolumn{2}{|c|}{ Loadings of Factor } & \multirow{2}{*}{$\mathrm{SE}$} & \multirow{2}{*}{$\begin{array}{c}\text { Squ. } \\
\text { Multiple } \\
\text { R } \\
\end{array}$} & \multirow{2}{*}{$\begin{array}{c}\text { Cronbach } \\
\boldsymbol{\alpha}\end{array}$} & \multirow{2}{*}{$\begin{array}{l}\text { Composite } \\
\text { Reliability* }\end{array}$} & \multirow{2}{*}{ AVE*: } \\
\hline & EFA & CFA & & & & & \\
\hline $\mathrm{BI}$ & & & & & 0.749 & 0.628 & 0.897 \\
\hline BI1 & .795 & 0.899 & $* * *$ & 0.807 & & & \\
\hline $\mathrm{BI} 2$ & .758 & 0.811 & 0.061 & 0.657 & & & \\
\hline BI3 & .607 & 0.631 & 0.055 & 0.186 & & & \\
\hline $\mathrm{BI} 4$ & .775 & 0.806 & 0.067 & 0.65 & & & \\
\hline $\mathrm{EE}$ & & & & & 0.823 & 0.672 & 0.925 \\
\hline EE1 & .684 & 0.762 & $* * *$ & 0.545 & & & \\
\hline EE2 & .776 & 0.878 & 0.061 & 0.794 & & & \\
\hline EE3 & .696 & 0.891 & 0.058 & 0.77 & & & \\
\hline EE4 & .681 & 0.738 & 0.061 & 0.581 & & & \\
\hline $\mathrm{PE}$ & & & & & 734 & 0.665 & 0.855 \\
\hline PE1 & .667 & 0.737 & $* * *$ & 0.002 & & & \\
\hline PE2 & .727 & 0.804 & 0.079 & 0.093 & & & \\
\hline PE3 & .746 & 0.898 & 0.072 & 3.019 & & & \\
\hline SI & & & & & 0.928 & 0.810 & 0.927 \\
\hline SI1 & .807 & 0.885 & $* * *$ & 0.783 & & & \\
\hline SI2 & .824 & 0.918 & 0.029 & 0.842 & & & \\
\hline SI3 & .802 & 0.898 & 0.03 & 0.807 & & & \\
\hline FC & & & & & 0.775 & 0.646 & 0.839 \\
\hline FC1 & .543 & 0.545 & $* * *$ & 0.297 & & & \\
\hline FC2 & .836 & 0.911 & 0.05 & 0.83 & & & \\
\hline FC3 & .796 & 0.901 & 0.05 & 0.838 & & & \\
\hline $\mathrm{HM}$ & & & & & 0.764 & 0.623 & 0.829 \\
\hline HM1 & .772 & 0.930 & $* * *$ & 0.864 & & & \\
\hline HM2 & .760 & 0.781 & 0.077 & 0.611 & & & \\
\hline HM3 & .654 & 0.630 & 0.112 & 0.397 & & & \\
\hline HA & & & & & 0.860 & 0.660 & 0.853 \\
\hline HAB1 & .753 & 0.751 & $* * *$ & 0.564 & & & \\
\hline HAB2 & .801 & 0.818 & 0.038 & 0.669 & & & \\
\hline HAB3 & .802 & 0.865 & 0.04 & 0.748 & & & \\
\hline PR & & & & & 0.877 & 0.524 & 0.881 \\
\hline PR1 & .754 & 0.940 & $* * *$ & 0.343 & & & \\
\hline
\end{tabular}


Table 3 Continued

\begin{tabular}{|c|c|c|c|c|c|c|c|}
\hline PR2 & .723 & 0.855 & 0.028 & 0.312 & & & \\
\hline PR3 & .706 & 0.630 & 0.028 & 0.452 & & & \\
\hline PR4 & .687 & 0.781 & 0.029 & 0.363 & & & \\
\hline PR5 & .955 & 0.930 & 0.025 & 0.913 & & & \\
\hline SC & & & & & 0.925 & 0.832 & 0.937 \\
\hline SC1 & .795 & .847 & $* * *$ & 0.717 & & & \\
\hline SC2 & .801 & .958 & 0.024 & 0.918 & & & \\
\hline SC3 & .842 & .929 & 0.027 & 0.863 & & & \\
\hline AT & & & & & 0.923 & 0.794 & 0.920 \\
\hline AT1 & .815 & .829 & $* * *$ & 0.687 & & & \\
\hline AT2 & .847 & .981 & 0.03 & 0.962 & & & \\
\hline AT3 & .723 & 0.857 & 0.034 & 0.734 & & & \\
\hline ST & & & & & 0.926 & 0.815 & 0.929 \\
\hline ST1 & .839 & 0.855 & $* * *$ & 0.732 & & & \\
\hline ST2 & .876 & 0.940 & 0.024 & 0.883 & & & \\
\hline ST3 & .891 & 0.912 & 0.027 & 0.833 & & & \\
\hline UB & & & & & 0.782 & 0.532 & 0.767 \\
\hline UB1 & .580 & .675 & $* * *$ & 0.075 & & & \\
\hline UB2 & .695 & 0.900 & 0.173 & 0.81 & & & \\
\hline UB3 & .554 & 0.575 & 0.101 & 0.271 & & & \\
\hline PEOU & & & & & 0.948 & 0.857 & 0.947 \\
\hline PEOU1 & .825 & .936 & $* * *$ & 0.877 & & & \\
\hline PEOU2 & .802 & .977 & 0.028 & 0.954 & & & \\
\hline PEOU3 & .779 & .861 & 0.029 & 0.741 & & & \\
\hline PU & & & & & 0.871 & 0.691 & 0.899 \\
\hline PU1 & .693 & .822 & $* * *$ & 0.675 & & & \\
\hline PU2 & .713 & .841 & 0.049 & 0.251 & & & \\
\hline PU3 & .750 & .882 & 0.052 & 0.778 & & & \\
\hline PU4 & .703 & .779 & 0.052 & 0.607 & & & \\
\hline FTFI & & & & & 0.950 & 0.840 & 0.940 \\
\hline FTFI1 & .826 & .902 & $* * *$ & 0.814 & & & \\
\hline FTFI2 & .854 & .978 & 0.028 & 0.957 & & & \\
\hline FTFI3 & .780 & .867 & 0.029 & 0.752 & & & \\
\hline Cumulative (\%) & 75.740 & & & & & & \\
\hline KMO & 0.839 & & & & & & \\
\hline P-value & 0.000 & & & & & & \\
\hline
\end{tabular}

Because the Kaiser-Meyer - Olkin test resulted in a score of 0.839 , all scale items were utilised to gather the latent variables investigated in the data analysis. The initial C.F.A. model provided a good match without eliminating any dimensions to create a better fitting measurement model. The quality of fit indicators of the primary examination pattern assessment recommended that the original model's findings be regarded as the final model. C.F.A. revealed that $\chi^{2}=4181.7$, p.001 suggest that the data match the measurement model. Furthermore, $\chi^{2} / \mathrm{df}$
$(4181.742 / 1655)=2.527$; this is an absolute match index for a severe point of view, with a threshold of 3.0 or 5.0 for suitable parameters. For acceptable constraints, the incremental fit index of 0.89 , the Tucker-Lewis index of 0.86 , the comparative fit index of 0.872 , and the projected average root square error of 0.0523 all surpass the 1.0 cutoff [65]. Based on these fit indices, the calculating model indicated a good match of the sample data.

The reliability and validity of the study model, factor loadings, Cronbach's alpha, composite reliability, and 
AVE were computed. The factor loadings were more than 0.500 [66, 67], indicating convergent validity. All aggregate dependability values surpassed 0.600 , indicating excellent internal reliability for the latent variables. LIKEWISE, every AVE value was more than 0.500 [65], proving convergent validity [68].

The structural equation modelling investigation yielded hypothesis testing findings, as shown in Figure 2 and Table 4.

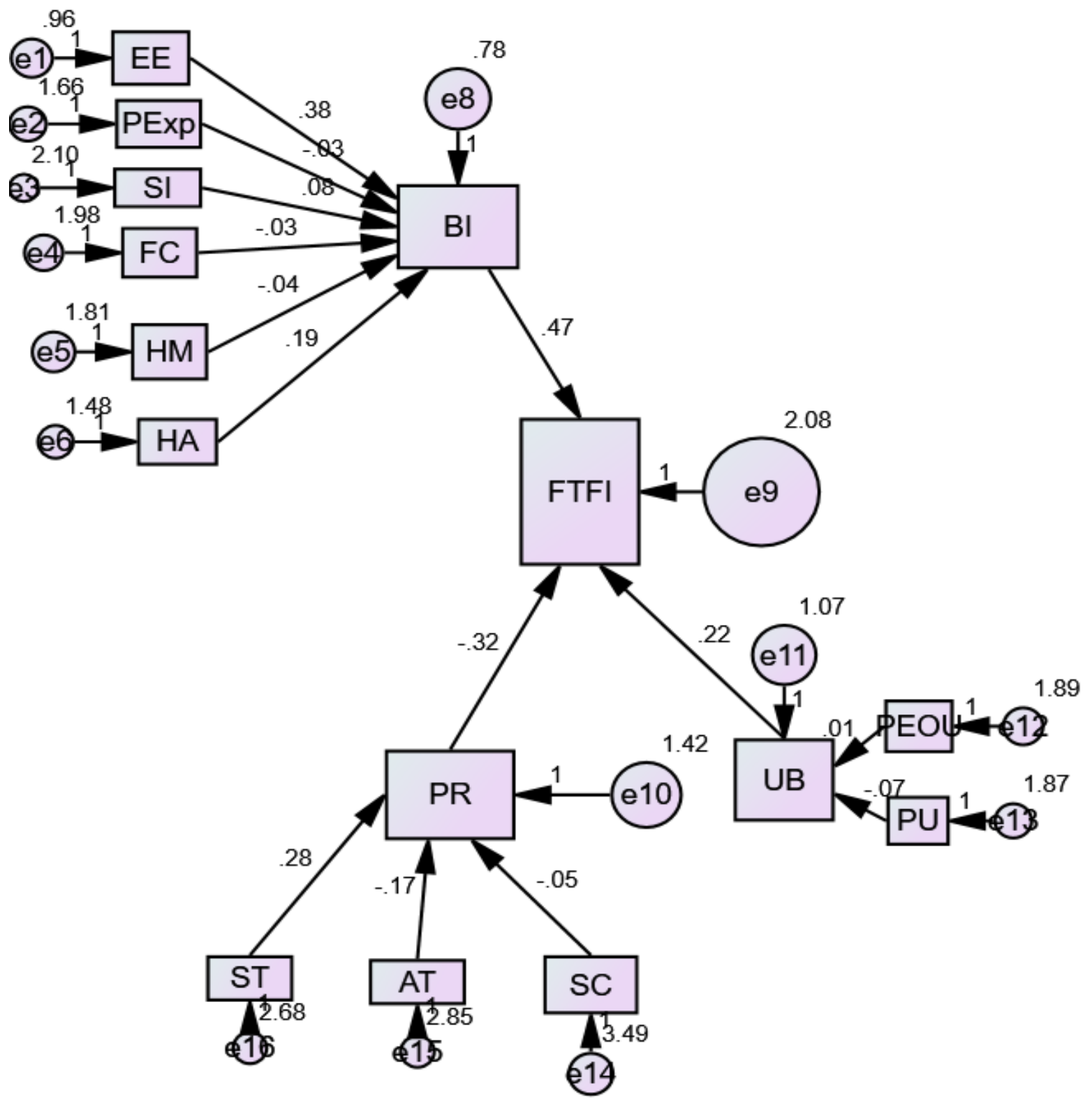

Figure 2. Path Diagram with Coefficients 
Table 4. Path analysis results $(P<.001)$

\begin{tabular}{|c|c|c|c|c|c|c|c|c|}
\hline Hypotheses & & Path & & Estimate & S.E. & C.R. & $\mathbf{P}$ & Result \\
\hline $\begin{array}{l}\text { H1: There is an association } \\
\text { between behavioural intention } \\
\text { and Effort Expectancy }\end{array}$ & B.I. & $<---$ & $\mathrm{EE}$ & .378 & .037 & 10.354 & $* * *$ & Supported \\
\hline $\begin{array}{l}\text { H2: There is an association } \\
\text { between behavioural intention } \\
\text { and Performance Expectancy }\end{array}$ & B.I. & $<---$ & PE & -.028 & .028 & -.993 & .321 & Not Supported \\
\hline $\begin{array}{l}\text { H3: There is an association } \\
\text { between behavioural intention } \\
\text { and social influence }\end{array}$ & B.I. & $<---$ & SI & .082 & .025 & 3.334 & $* * *$ & Supported \\
\hline $\begin{array}{l}\text { H4: There is an association } \\
\text { between behavioural intention } \\
\text { and Facilitating Condition }\end{array}$ & B.I. & $<---$ & FC & -.030 & .025 & -1.185 & .236 & Not Supported \\
\hline $\begin{array}{l}\text { H5: There is an association } \\
\text { between behavioural intention } \\
\text { and Motivation }\end{array}$ & B.I. & $<---$ & $\mathrm{HM}$ & -.041 & .027 & -1.541 & .123 & Not Supported \\
\hline $\begin{array}{l}\text { H6: There is an association } \\
\text { between behavioural intention } \\
\text { and end-user Habit }\end{array}$ & B.I. & $<---$ & HA & .192 & .029 & 6.505 & $* * *$ & Supported \\
\hline $\begin{array}{l}\text { H9: There is an association } \\
\text { between Perceived Risk and } \\
\text { Service Trust }\end{array}$ & PR & $<---$ & ST & .283 & .030 & 9.544 & $* * *$ & Supported \\
\hline $\begin{array}{l}\text { H8: There is an association } \\
\text { between Perceived Risk and } \\
\text { Agent Trust }\end{array}$ & PR & $<---$ & $\mathrm{AT}$ & -.169 & .029 & -5.897 & $* * *$ & Supported \\
\hline $\begin{array}{l}\text { H7: There is an association } \\
\text { between Perceived Risk and } \\
\text { Service Charge }\end{array}$ & PR & $<---$ & SC & -.051 & .026 & -1.968 & .047 & Supported \\
\hline $\begin{array}{l}\text { H11: There is an association } \\
\text { between Usability and } \\
\text { Perceived usefulness }\end{array}$ & U.B. & $<---$ & PU & -.071 & .031 & -2.309 & .021 & Supported \\
\hline $\begin{array}{l}\text { H10: There is an association } \\
\text { between Usability and } \\
\text { Perceived ease-of-use }\end{array}$ & U.B. & $<---$ & PEOU & .007 & .031 & .222 & .824 & Not Supported \\
\hline $\begin{array}{l}\text { H12: There is an association } \\
\text { between behavioural intention } \\
\text { and use of FinTech for } \\
\text { Financial inclusion }\end{array}$ & FTFI & $<---$ & BI & .472 & .059 & 8.007 & $* * *$ & Supported \\
\hline $\begin{array}{l}\text { H13: There is an association } \\
\text { between perceived risk and } \\
\text { use of FinTech for Financial } \\
\text { inclusion }\end{array}$ & FTFI & $<---$ & PR & -.318 & .045 & -7.127 & $* * *$ & Supported \\
\hline $\begin{array}{l}\text { H14: There is an association } \\
\text { between usability and use of } \\
\text { FinTech for Financial inclusion }\end{array}$ & FTFI & $<---$ & UB & .219 & .056 & 3.875 & $* * *$ & Supported \\
\hline
\end{tabular}

Group number 1 (Group number 1 - Default model) Estimates (Group number 1 - Default model) Scalar Estimates (Group number 1 - Default model) Maximum Likelihood Estimates

Regression Weights: (Group number 1 - Default model) Variances: (Group number 1 - Default model)

Minimization History (Default model)

Model Fit Summary

\section{CMIN}

In addition, path analysis was used to examine the structural model. The model is also determined to be fit since the fit indices G.F.I., N.I.F., TLI and CFI are all more than 0.9, and the RMSEA is less than 0.08. We evaluated the study hypotheses using the statistical significance of the uniform regression weights for endogenous test variables (i.e. $t$ value) and the coefficient of measurement $\mathrm{R}^{2}[69]$. The result of the path diagram shows that there is a positive relationship between behavioural intention and effort expectancy. The factors constructing the social influence also positively impact behavioural intention to use manager technology in the rural sector in India. An end-user habit of using financial technology systems and services has a positive relationship with behavioural intention. The relationship between service charge, agent 
trust and service trust positively influence the perceived risk in using financial Technology Services. Factors affecting perceived ease of use towards using the financial technology are positively related to the system's usability. Moreover, results of path analysis also reveal that the positive behavioral intention to use manager Technology and the usability of the system is positively affecting the use of Financial Technology for financial inclusion in rural India; however, the perceived risk is found to be negatively associated with the use of Financial Technology systems in the rural Indian context.

\section{Conclusions}

Financial inclusion is widely recognised as essential for poverty reduction, balanced economic development, and economic stability. A large part of the population does not have a basic bank account in developing countries. The majority of them belong to Asia and the Middle East. Essential financial services like banking remain an unrealised dream for millions of people, especially for citizens in rural and remote regions in India. The usage of financial technology and mobile money services is required for transaction reasons and to alter one's livelihood by investing in the development of new businesses or self-employment initiatives. These efforts are gaining traction quickly thanks to the sharing economy, laws, and information technology. However, research in the area of FinTech is still in its early stages. Based upon the extensive literature review and discussions with representatives of the key players, the proposed study appears more contextual in the current situation by investigating the critical success factors at the different levels of adoption of financial technologies [68]. Financial inclusion is a development priority for policy-makers in most developing countries.

This paper adds to the literature dealing with the determinants of Fintech with financial inclusion, especially for the financially challenged people for the rural India. The main conclusion emerged from this empirical research is the model that includes the rural people with the Finance. Further, the results for S.E.M. and path analysis concluded that consumers are intended to be part of financial inclusion with the use of FinTech services, always try to use FinTech based mobile services for transactions. They plan to continue using FinTech for Financial Inclusion and find services easy to use. Most respondents are using FinTech based financial inclusion services frequently and perceive that this has improved profitability and savings and allowed them to send money inexpensively to anyone in the world [69]. People in Rural India believe that Fintech can be used for Financial Inclusion and can be used for income improvement in rural India.

Respondents from Rural India believe in FinTech based financial inclusion Techniques and found that their interaction with FinTech based financial inclusion services is easy and understandable. People around that expected that they should use FinTech based financial inclusion services, also influence behaviour. Some users also presented a view that the use of FinTech based financial inclusion services has become a habit. However, the user also shows concern, and they think using FinTech based financial inclusion services puts privacy at risk. People perceive that service charges under FinTech based financial inclusion are reasonable and value for money. They also showed trust in agents facilitating conditions in providing FinTech services. But they also find it necessary to be cautious with FinTech based financial inclusion services.

\section{Implications}

Present work provides emerging good practices for policy-makers, regulators, and investors in changing financial environment. It presents empirical findings to identify the critical success factor and another growth driver for FinTech services. The results of this study provide necessary inputs to the decision-makers, including service providers like payment banks, mobile money partners, government, law enforcement agencies for developing a strategy to navigate the existing barriers for inclusive financial growth. Drawing from insight from the study, Policy-makers and industry stakeholders may use mobile phone technology to create policies and new service offers to improve employment, income, and citizen well-being. The paper helps in the creation of a citizen dataset of financial technology beneficiaries. The results would help mobile service industry to discover an economy of scope in providing services at low cost and with maximum social benefits. Study will also provide insights to financial institutions offers banking services via mobile to handle cross-border transactions to low-income customers of remote areas. Finding of the study also add to the existing literature of financial inclusion interventions in developing countries [69].

Large populations in emerging nations like India see financial access as a significant barrier to development. The current study's findings help society in two ways. First, they will know about accessible savings, microcredits, insurance, and payment and transfer services. Secondly, financial inclusion allows previously excluded individuals to access growth. Inclusive financial sector development makes complementary contributions by attracting more people to the economy and ultimately helps develop rural regions. Entrepreneurship possesses immense societal implications beyond its commercial significance [71]. Inclusive financial growth and entrepreneurship can reduce poverty by financing growth factors like mobilising savings and providing access to services to poor people, reducing vulnerability and improving social welfare. 


\section{REFERENCES}

[1] Oskarsson, P., "Landlock: paralysing dispute over minerals on Adivasi land in India” A.N.U. Press, 2018, pp. 204. DOI: 10.22459/10.22459/L.09.2018

[2] Oskarsson, P., "The law of the land contested: Bauxite mining in tribal, central India in an age of economic reform”, Doctoral dissertation, University of East Anglia, 2010.

[3] Chouhan, V., Sharma, R.B. and Goswami, S., "Measuring challenges in adoption of sustainable environmental technologies in Indian cement industry,” Accounting, vol. 7, vo. 2, pp. 339-348, 2021. doi: 10.5267/j.ac.2020.11.019

[4] Chouhan, V., Sharma, R.B., Goswami, S. and Hashed, A.W.A., "Sustainable reporting: a case study of selected cement companies of India,” Accounting, vol. 7, no. 1, pp. 151-160,2021.DOI: 10.5267/j.ac.2020.10.002

[5] Chouhan, V., Vasita, M. L., \& Goswami, S., "The impact and role of social media for consciousness of COVID-19 pandemic," Journal of Content, Community and Communication, vol. 12, pp. 250-262, 2020. DOI: 10.31620/JCCC.12.20/23.

[6] Chouhan, V., Soral, G. and Chandra, B., "Activity based costing model for inventory valuation”, Management Science Letters, vol. 7, no. (1), pp. 135-144. 2017. doi: 10.5267/j.msl.2016.12.003

[7] Chouhan, Vineet, Sharma, Raj Bahadur, Vasita, M. L. and Goswami, Shubham.,"Chapter 4 Measuring barriers in adoption of blockchain in supply chain management system," Blockchain 3.0 for Sustainable Development, edited by Deepak Khazanchi, Ajay Kumar Vyas, Kamal Kant Hiran and SanjeevikumarPadmanaban, Berlin, Boston: De Gruyter, pp. 202, pp. 37-62.https://doi.org/10.1515/97 83110702507

[8] Khan, H. R., "Issues and challenges in financial inclusion: Policies, partnerships, processes and products,” Korea, vol.18, no. 250.29, pp.84-17, 2020.

[9] Okoye, L. U., Adetiloye, K. A., Erin, O., \& Modebe, N. J., "Financial inclusion as a strategy for enhanced economic growth and development,” Journal of Internet Banking and Commerce, vol. 22, no. S8, 2017.

[10] Chang, V., Baudier, P., Zhang, H., Xu, Q., Zhang, J., \& Arami, M., "How Blockchain can impact financial services-The overview, challenges and recommendations from expert interviewees," Technological forecasting and social change, vol.158, no.1, pp.120-166, 2020. doi: 10.1016/j.techfore.2020.120166

[11] Schuetz, S., \& Venkatesh, V., "Blockchain, adoption, and financial inclusion in India: Research opportunities," International Journal of Information Management, vol.52, pp.101936, 2020. https://doi.org/10.1016/j.ijinfomgt.2019. 04.009

[12] Mannan, M., \& Pek, S., "Solidarity in the sharing economy: The role of platform cooperatives at the base of the pyramid,” In Sharing Economy at the Base of the Pyramid. Springer, Singapore, 2021, pp. 249-279. DOI: 10.1007/978-981-16-2414-8_11.

[13] Gautam, A., \& Rawat, S., "Cashless and Digital Economy and its Effect on Financial Inclusion in India, financial sector in India Issues, Challenges \& Opportunities,” Excel publication, 2017, pp.77-85.

[14] Haque, S. S., Yanez-Pagans, M., Arias-Granada, Y., \& Joseph, G., "Water and sanitation in Dhaka slums: access, quality, and informality in service provision," Water International, vol. 45, no. 7-8, pp. 791-811, 2020. https://doi.org/10.1080/02508060.2020.1786878

[15] Metzger, M., Riedler, T., \& Pédussel Wu, J., "Migrant remittances: Alternative money transfer channels," Working Paper.2019, No. 127/2019.

[16] Chouhan, V., Goswami, S., Dadhich, M., Saraswat, P. \& Shakdwipee, P., "Chapter 5 Emerging opportunities for the application of blockchain for energy efficiency," In D. Khazanchi, A. Kumar Vyas, K. Kant Hiran \& S. Padmanaban (Ed.), Blockchain 3.0 for Sustainable Development. Berlin, Boston: De Gruyter, 2021, pp. 63-88. https://doi.org/10.1515/9783110702507

[17] Anagnostopoulos, I., "Fintech and regtech: Impact on regulators and banks,” Journal of Economics and Business, vol. 100, pp. 7-25, 2018

[18] Li, F., Lu, H., Hou, M., Cui, K., \& Darbandi, M., "Customer satisfaction with bank services: The role of cloud services, security, e-learning and service quality,” Technology in Society, vol. 64, pp. 101487, 2021. https://doi.org/10.1016/j.techsoc.2020.101487

[19] Chouhan, V., Goswami, S and Sharma, RB., "Use of proactive spare parts inventory management (PSPIM) techniques for material handling vis-à-vis cement industry,” Materials Today: Proceedings, vol. 45, no. 6, 4383-4389, 2021, https://doi.org/10.1016/j.matpr.2020.11.757.

[20] Omojolaibi, J. A., Okudo, A. G., \& Shojobi, D. A., “Are women financially excluded from formal financial services? Analysis of some selected local government areas in Lagos State, Nigeria,” Journal of Economic and Social Thought, vol. 6, no. 1, no. 16-47, 2019.

[21] Chouhan, V, Chandra, B, Saraswat, P. and Goswami, S., "Developing sustainable accounting framework for cement industry: evidence from India,” Finance India, vol. 34, no. 4, 1459-1474, 2020

[22] Reddy, A. K., "Impact OF E-Banking on Customer Satisfaction," PalArch's Journal of Archaeology of Egypt/Egyptology, vol. 18, no. 08, pp. 4220-4231, 2021.

[23] Menz, M., Kunisch, S., Birkinshaw, J., Collis, D. J., Foss, N. J., Hoskisson, R. E., \& Prescott, J. E., "Corporate Strategy and the Theory of the Firm in the Digital Age,” Journal of Management Studies, vol. 58, no. 7, pp.1695-1720, 2021. doi:10.1111/joms.12760.

[24] He, M. D., Leckow, M. R. B., Haksar, M. V., Griffoli, M. T. M., Jenkinson, N., Kashima, M. M., ... \& Tourpe, H., "Fintech and financial services: initial considerations," International Monetary Fund. 2017, pp. 49, https://doi.org/ 10.5089/9781484303771.006

[25] Cecchetti, S. G., \& Schoenholtz, K. L., Finance and Technology: What is changing and what is not. Korea Institute of Finance, pp. 1-40, 2020.

[26] Mader, P., “Contesting financial inclusion,” Development and change, vol. 49, no. 2, pp.461-483, 2018.

[27] Kim, M., Zoo, H., Lee, H., \& Kang, J., “Mobile financial 
services, financial inclusion, and development: A systematic review of academic literature,” The Electronic Journal of Information Systems in Developing Countries, vol. 84, no.5, pp. e12044, 2018. https://doi.org/10.1002/isd 2.12044 .

[28] Chouhan, V., "Investigating Factors Affecting Electronic Word-of-Mouth,” In Capturing, Analyzing, and Managing Word-of-Mouth in the Digital Marketplace, IGI Global. 2016, pp. 119-135, DOI:10.4018/978-1-4666-9449-1.ch00 7

[29] Khan, S., Chouhan, V., Chandra, B and Goswami, S., "Sustainable accounting reporting practices of Indian cement industry: An exploratory study," Uncertain Supply Chain Management, vol. 2, no. 1, pp. 61-72, 2014.doi: 10.5267/j.uscm.2014.2.001

[30] Maina, EM., Chouhan, V. and Goswami, S., "Measuring Behavioral Aspect of IFRS Implementation in India And Kenya,” International Journal of Scientific \& Technology Research, vol. 9, no. 1, pp. 2045-2048, 2020.

[31] Burns, S., "M - Pesa and the 'market - led' approach to financial inclusion,” Economic Affairs, vol, 38, no. 3, pp. 406-421, 2018. https://doi.org/10.1111/ecaf.12321

[32] Duncombe, R., \& Boateng, R., "Mobile Phones and Financial Services in Developing Countries: a review of concepts, methods, issues, evidence and future research directions," Third World Quarterly, vol. 30, no. 7, pp.1237-1258, 2009. https://doi.org/10.1080/01436590903 134882 .

[33] Wry, T., \& Zhao, E. Y., “Taking trade-offs seriously: Examining the contextually contingent relationship between social outreach intensity and financial sustainability in global microfinance," Organization Science, Vol. 29, No. 3, pp. 507-528, 2018. https://doi.org/10.1287/orsc.2017.1188.

[34] Iqbal, S., Nawaz, A., \& Ehsan, S., "Financial performance and corporate governance in microfinance: Evidence from Asia,” Journal of Asian Economics, vol. 60, pp. 1-13, 2019. https://doi.org/10.1016/j.asieco.2018.10.002

[35] Chavan, P., \& Birajdar, B., "Micro finance and financial inclusion of women: An evaluation,” Reserve Bank of India Occasional Papers, vol. 30, no. 2, pp. 109-129, 2009.

[36] Mia, M. A., Zhang, M., Zhang, C., \& Kim, Y., “Are microfinance institutions in south-East Asia pursuing objectives of Greening the Environment?,” Journal of the Asia Pacific Economy, vol. 23, no. 2, pp. 229-245, 2018. https://doi.org/10.1080/13547860.2018.1442147

[37] Jack, W., \& Suri, T., "Risk sharing and transactions costs: Evidence from Kenya's Mobile Money Revolution," American Economic Review, vol. 104, no. 1, pp. 183-223, 2014. 10.1257/aer.104.1.183

[38] Frost, J., Gambacorta, L., Huang, Y., Shin, H. S., \& Zbinden, P., "BigTech and the changing structure of financial intermediation,” Economic Policy, vol. 34, no. 100, pp. 761-799, 2019. https://doi.org/10.1093/epolic/eia $\mathrm{a} 003$.

[39] Apiors, E. K., \& Suzuki, A. , “Mobile money, individuals' payments, remittances, and investments: Evidence from the Ashanti Region, Ghana,” Sustainability, vol. 10, no. 5, p. 1409, 2018. https://doi.org/10.3390/su10051409.
[40] Riley, E., "Mobile money and risk sharing against village shocks," Journal of Development Economics, vol. 135, pp. 43-58, 2018. https://doi.org/10.1016/j.jdeveco.2018.06.01 5.

[41] Aron, J., "Mobile money and the Economy: A Review of the evidence,” The World Bank Research Observer, vol. 33, no. 2, pp. 135-188, 2018. https://doi.org/10.1093/wbro/lky 001

[42] Mbiti, I., \& Weil, D. N., "The home economics of E-Money: Velocity, cash management, and discount rates of M-Pesa users,” American Economic Review, vol. 103, no. 3, pp. 369-374, 2013.10.1257/aer.103.3.369.

[43] Wieser, C., Bruhn, M., Kinzinger, J. P., Ruckteschler, C. S., \&Heitmann, S., "The impact of mobile money on poor rural households: Experimental evidence from Uganda”. World Bank Policy Research Working Paper, pp.8913, 2019.

[44] Ghosh, S., "Financial Inclusion in India: Does distance matter?," South Asia Economic Journal, vol. 21, no. 2, pp. 216-238, 2020. https://doi.org/10.1177/139156142096164 9.

[45] Masino, S., \& Niño-Zarazúa, M., "Improving financial inclusion through the delivery of cash transfer programmes: The case of Mexico's Progresa-Oportunidades-Prospera Programme,” The Journal of Development Studies, vol. 56, no. 1, pp. 151-168, 2018. https://doi.org/10.1080/0022038 8.2018.1546845.

[46] Rathod, S., \& Arelli, S. K. P., "Aadhaar and financial inclusion: A proposed framework to provide basic financial services in unbanked rural India,” Driving the Economy through Innovation and Entrepreneurship, pp. 731-744, 2013.https://doi.org/10.1007/978-81-322-0746-7_60.

[47] Singh, S., Goyal, S. K., \& Sharma, S. K., “Technical efficiency and its determinants in microfinance institutions in India: a firm level analysis," Journal of Innovation Economics Management, vol. 1, pp.15-31, 2013. https://doi.org/10.3917/jie.011.0015.

[48] Singh, N. D., \& Singh, H. R., "Social impact of microfinance on S.H.G. members: A case study of Manipur," Prabandhan: Indian Journal of Management, vol. 5, no. 3, pp. 43-50, 2012.https://doi.org/10.17010/pijom/2012/v5i3/ 60155

[49] Fang, J., Russell, R., \& Singh, S., "Exploring the impact of mobile money services on marketing interactions in relation to consumer well-being in subsistence marketplaceslessons from rural Cambodia,” Journal of Marketing Management, vol. 30, no. 5-6, pp. 445-475, 2014. https://doi.org/10.1080/0267257X.2014.884619.

[50] Senyo, P. K., \& Osabutey, E. L., "Unearthing antecedents to financial inclusion through FinTech innovations," Technovation, vol. 98, pp.102155, 2020.https://doi.org/10. 1016/j.technovation.2020.102155

[51] Venkatesh, V., Thong, J.Y.L., Xu, X., “Consumer acceptance and use of information technology: Extending the unified theory of acceptance and use of Technology," MIS Quarterly, vol. 36, no. 1, p. 157, 2012. https://doi.org/10.2307/41410412

[52] Gefen, D., Karahanna, E., Straub, D.W., , “Trust and tam in online shopping: An integrated model,” MIS Quarterly, vol. 27, no. 1, p. 51, 2003. https://doi.org/10.2307/30036519 
[53] Pavlou, P.A., “Consumer acceptance of Electronic Commerce: Integrating Trust and Risk with the technology acceptance model," International Journal of Electronic Commerce, vol. 7, no. 3, pp. 101-134, 2003. https://doi.org/10.1080/10864415.2003.11044275.

[54] Meyliana, M., \& Fernando, E. , "The influence of perceived risk and trust in adoption of fintech services in Indonesia," CommIT (Communication and Information Technology) Journal, vol. 13, no. 1, p. 31, 2019. https://doi.org/10.2151 2/commit.v13i1.5708.

[55] Rose, J., \& Fogarty, G. J... "Determinants of perceived usefulness and perceived ease of use in the technology acceptance model: senior consumers' adoption of self-service banking technologies” In Proceedings of the 2nd Biennial Conference of the Academy of World Business, Marketing and Management Development: Business Across Borders in the 21st Century (Vol. 2, pp. 122-129). Academy of World Business, Marketing and Management Development.2006.

[56] Davis, F. D., "Perceived usefulness, perceived ease of use, and user acceptance of Information Technology," MIS Quarterly, vol. 13, no. 3, p. 319, 1989. https://doi.org/10.2 $307 / 249008$.

[57] Subramanian, G. H., “A replication of perceived usefulness and perceived ease of use measurement," Decision Sciences, vol. 25, no. 5-6, pp. 863-874, 1994, https://doi.org/10.111 1/j.1540-5915.1994.tb01873.x.

[58] Demir, A., Pesqué-Cela, V., Altunbas, Y., \& Murinde, V. , "Fintech, financial inclusion and income inequality: A quantile regression approach," The European Journal of Finance, pp. 1-22, 2020. https://doi.org/10.1080/1351847 X.2020.1772335.

[59] Thomas, H., \& Hedrick-Wong, Y. , "How digital finance and Fintech can improve financial inclusion,” Inclusive Growth, pp. 27-41, 2019.https://doi.org/10.1108/978-1-78 973-779-020191004.

[60] Chouhan, V, Sharma, R.B., Goswami, S. "Factor Affecting Audit Quality: a study of the companies listed in Bombay Stock Exchange (B.S.E.)," International Journal of Management, vol. 11, no. 7, pp. 989-999. 2021.

[61] Ajzen, I., \& Fishbein, M., "A bayesian analysis of attribution processes.,” Psychological Bulletin, vol. 82, no. 2, pp. 261-277, 1975.https://doi.org/10.1037/h0076477.

[62] Ajzen, I., “The theory of planned behavior,” Organizational
Behavior and Human Decision Processes, vol. 50, no. 2, pp. 179-211, 1991. https://doi.org/10.1016/0749-5978(91)900 20-T.

[63] Davis, F. D., , "Perceived usefulness, perceived ease of use, and user acceptance of Information Technology," MIS Quarterly, vol. 13, no. 3, p. 319, 1989. https://doi.org/10.2 $307 / 249008$

[64] Venkatesh, V., Morris, M. G., Davis, G. B., \& Davis, F. D. , "Consumer acceptance and use of information technology: Extending the unified theory of acceptance and use of Technology,” MIS Quarterly, vol. 36, no. 1, p. 157, 2012. https://doi.org/10.2307/41410412.

[65] Lai, M., Wu, W. Y., \& Lin, S. M., “A qualitative approach for conceptualizing consumer decision-making in online auctions,” ACR North American Advances. 2008.

[66] Black, W., \& Babin, B. J., "Multivariate Data Analysis: Its approach, evolution, and impact," The Great Facilitator, pp. 121-130, 2019. 10.1007/978-3-030-06031-2_16.

[67] Creswell, J. W., "Editorial: Mapping the field of Mixed Methods Research,” Journal of Mixed Methods Research, vol. 3, no. 2, pp. 95-108, 2008. https://doi.org/10.1177/155 8689808330883.

[68] Udoh, B. E., Jack, A. E., Prince, A. I., Ekeowa, K. I. L., Ndubuaku, V., \& Samuel, U. E. "Financial Deepening and Economic Growth in Nigeria: ARDL and NARDL Techniques," Universal Journal of Accounting and Finance, Vol. 9, no. 4, pp. 667-677.2021. https://doi.org/10.13189/ujaf.2021.090413

[69] Orlov, E. V., Rogulenko, T. M., Smolyakov, O. A., Oshovskaya, N. V., Zvorykina, T. I., Rostanets, V. G., \& Dyundik, E. P., "Comparative Analysis of the Use of Kanban and Scrum Methodologies in IT Projects," Universal Journal of Accounting and Finance, vol. 9, no. 4, pp. 693-700. 2021. https://doi.org/10.13189/ujaf.2021.090 415

[70] Bagozzi, R. P., \& Yi, Y. , “On the evaluation of structural equation models," Journal of the academy of marketing science, vol. 16, no. 1,pp. 74-94. 1998. https://doi.org/10.1 007/BF02723327.

[71] Russell, J. A., "Evidence of convergent validity on the dimensions of affect," Journal of personality and social psychology, vol. 36, no. 10, pp. 1152-1168. 1978. https://doi.org/10.1037/0022-3514.36.10.1152. 